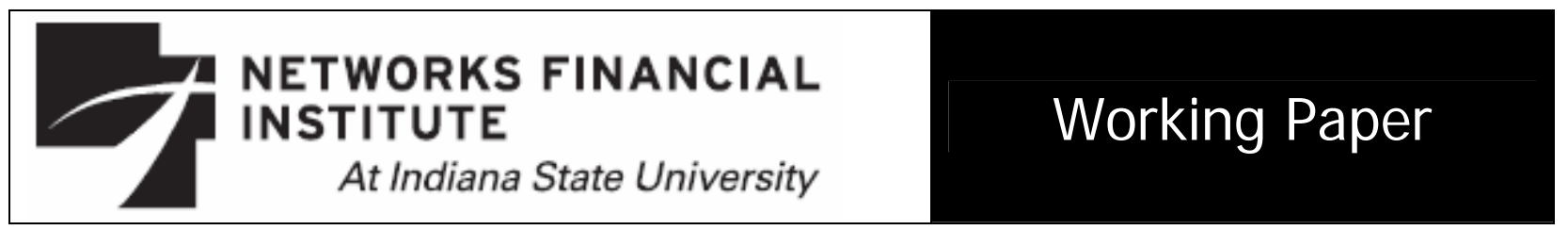

2005-WP-03

November 2005

\title{
Banking and Economic Development in Morocco
} John A. Tatom

Abstract: In Morocco, as elsewhere, banking is the principal financial sector it has the potential to contribute the most or to most severely retard economic development. But the banking industry's potential performance is constrained by the monetary policies of the central bank. This paper reviews some major factors favoring a strong banking industry that boosts development, as well as the major obstacles that have or continue to face the industry and the economy. The Moroccan central bank, Bank al'Magrib, has been very successful in providing a strong financial environment for the nation. Within this environment, indeed, perhaps because of it, the nation's banking sector is performing very well. One of the main recent achievements has been the near elimination of so-called "specialized banks," government institutions set up to provide directed credit to key sectors of the economy. These banks were a major drag on the private financial sector, boosting risk and raising costs, lowering returns to private banks and reducing the their supply of credit and raising the cost of credit for the private sector. These institutions have largely been merged into private firms and their special status eliminated. Fiscal policy continues to remain a major barrier to private capital formation and bank lending. Unfortunately government policy continues to favor running large budget deficits, continuing the waste of scarce national resources. In addition, very high marginal tax rates kick in at very low levels of income, penalizing saving and investment and risk-taking activity.

About the Author: John A. Tatom is the Director of Research at Networks Financial Institute, part of Indiana State University, and Associate Professor of Finance at Indiana State University. He has published widely on international and domestic monetary and fiscal policy issues, especially inflation, capital formation, productivity and growth; the macroeconomics of supply, especially oil and energy price shocks; the relationship of exchange rate movements to international competitiveness, capital flows, trade, and international economic policy; and on financial innovations and their effects on monetary policy and the economy, among other areas.

Keywords: banking, budget deficit, exchange rates, inflation, development

The views expressed are those of the individual author and do not necessarily reflect official positions of Networks Financial Institute. Please address questions regarding content to John Tatom at john.tatom@isunetworks.org. Any errors or omissions are the responsibility of the author.

NFI working papers and other publications are available on NFI's website (www. networksfinancialinstitute.org). Click "Research" and then "Publications/Papers." 


\section{Banking and Economic Development in Morocco* John A. Tatom}

Banking is typically the principal financial industry and has the potential to contribute the most or to most severely retard economic development in a country. But the banking industry's potential performance is constrained by the monetary policies of the central bank. This paper reviews some major factors favoring a strong banking industry that boosts development, as well as the major obstacles that have or continue to face the industry and the economy. In the case of Morocco, the central bank, Bank al'Magrib, has been very successful in providing a strong financial environment for the nation. Within this environment, indeed, perhaps because of it, the nation's banking sector is performing very well. One of the main achievements of recent years has been the near elimination of so-called "specialized banks," government institutions set up to provide directed credit to key sectors of the economy. These banks were a major drag on the private financial sector, boosting risk and raising costs, lowering returns to private banks and reducing the their supply of credit and raising the cost of credit for the private sector. These institutions have largely been merged into private firms and their special status eliminated. Fiscal policy continues to remain a major barrier to private capital formation and bank lending. Unfortunately government policy continues to favor running large budget deficits, continuing the waste of scarce national resources.

\section{Strong monetary policy and financial deepening}

Monetary policy has been very successful in Morocco, at least as judged by inflation performance. Chart 1 shows the inflation rate since 1960. The inflation rate fell to relatively low levels after 1986 and reached internationally competitive levels after 1995, remaining at a pace that is comparable to that in the advanced countries, especially Western Europe and the US. This has occurred because of the success of the central bank in attempting to lower inflation. In particular, following a slight surge in inflation in the early-1990s, the central bank moved to bring it down by targeting a weighted average exchange rate (Chart 2). The exchange rate reflects the relative importance of the euroarea as the principal trading partner and the stability of the trade-weighted exchange rate since the mid-1990s is reflected in the very low average inflation rate in Morocco since then.

\footnotetext{
* This paper was prepared for the Networks Financial Institute Conference (co-sponsored with Indiana State University and Hassan II University-Mohammedia) on "The Financial System and Economic Development," September 19-20, Casablanca, Morocco.
} 


\section{Chart 1}

\section{Inflation has been relatively low since the mid-1980s}

Inflation has slowed to an internationally competitive pace

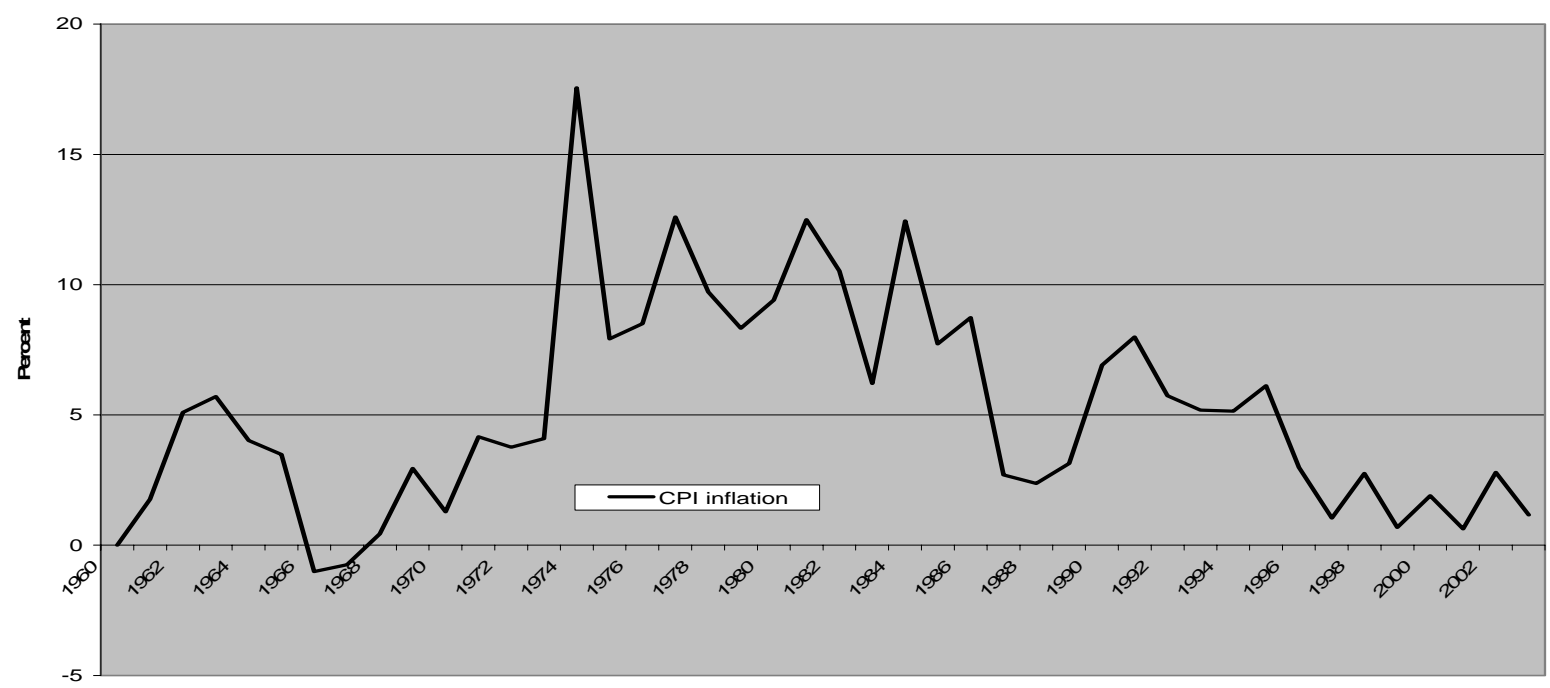

\section{Chart 2}

The dirham has been relatively stable against foreign currencies since the mid-1990s

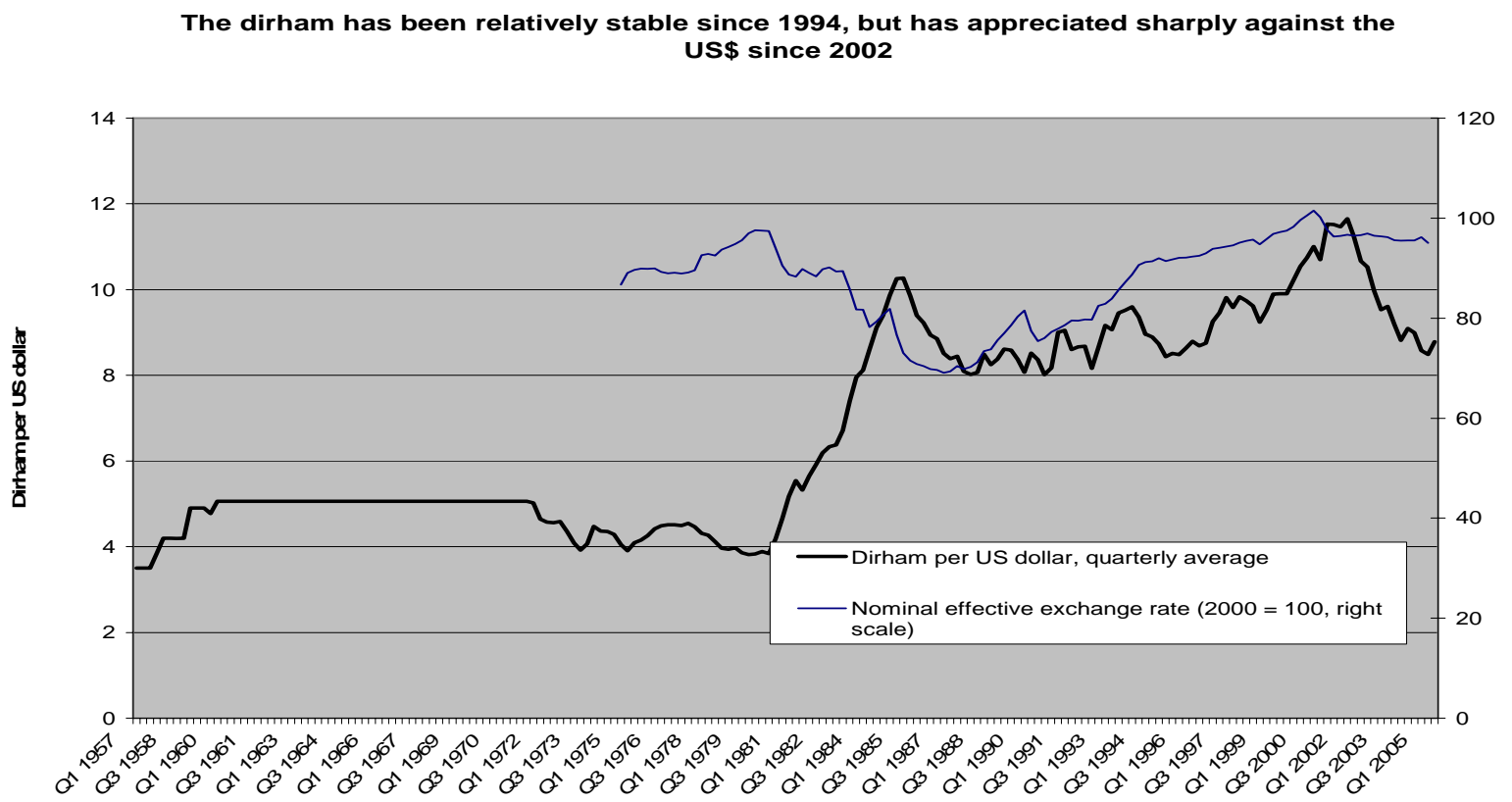

Monetary policy that protects domestic and foreign investors from inflation makes holding assets denominated in local currency, the dirham, more attractive, including bank deposits. By raising the demand for banking sector liabilities, monetary policy has fostered financial deepening, the growth of domestic monetary assets relative to the nation's income or GDP. Chart 3 shows that financial deepening, measured by the rise in the ratio of the monetary aggregate M2 to GDP, accelerated starting in the mid-1980s and has continued since. This 
has made the banking sector much larger relative to the size of the economy that it would otherwise have been. For example, the ratio of M2 to GDP has risen from about 40 percent in the mid-1980s to over 90 percent today. This means that M2 and the size of the banking sector is over twice as large as it would have been without the financial deepening that took place over the past 20 years. Note that this boost in the size of the banking sector to 90 percent of GDP includes the induced effects that a larger financial sector has on the productivity and income of the country because GDP is also larger because of the successful monetary policy of the country. By increasing the size of bank assets, financial deepening has also increased the supply of bank credit to the economy and on terms that are much more favorable than would have been the case had inflation been allowed to run higher as it did in some other countries in the region and in most other developing and emerging economies.

\section{Chart 3}

\section{Financial deepening has raised the share of Money in GDP to a level comparable to that of many developed countries}

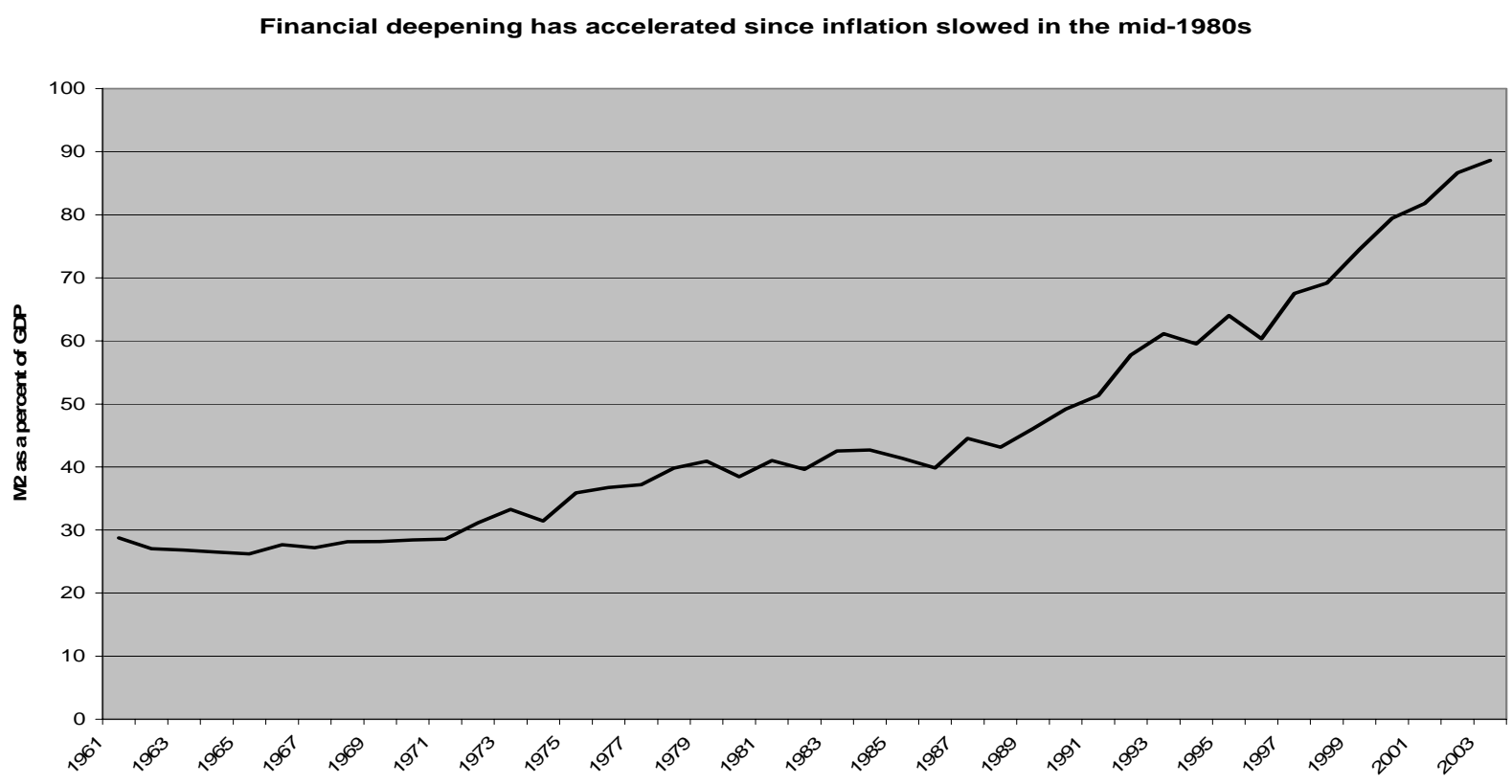

The increased attractiveness of dirham denominated assets and confidence in the central bank's efforts to secure price stability has lowered risk premia on longer-term investment in Morocco, making investment more attractive for domestic and foreign investors. As a result foreign investment has risen to about 5 percent of GDP in recent years. There are many other reasons, especially privatization efforts of the government, for the rise in foreign investment, but the upward trend in foreign investment preceded and has persisted beyond some outsized privatizations earlier in this decade. Similarly, overall investment in new plant, equipment and software has been relatively high for the past decade because of the lower inflation and its related lower cost of capital to finance investment. And 
investment is critical for boosting productivity. While there are productivity concerns in Morocco, monetary policy has been doing its part to boost investment and productivity.

\section{The banking sector is strong and strengthening}

It should not be surprising that Morocco has a strong banking sector given the financial deepening that has taken place, especially over the past 20 years. Nonetheless, the progress in financial sector development was seriously hobbled by the government's creation of specialized banks to provide directed credit on favorable terms to favored industries. There were, until recently, four main specialized banks created to channel credit to agriculture, industry, local government, tourism and housing and the projects of Moroccans living abroad. The IMF called attention to the problems posed by specialized banks (2003), but El Aynaoui (2005) points out that these institutions have been and eventually all will be merged into the private financial system and their special status as borrowers and lenders has been eliminated. There are other weaknesses in the banking sector, including high concentration that extends to the insurance and asset management components of the financial system, besides the specialized banks, but they were the principal burden to the financial system until recently and also a key burden to the government budget which subsidized their losses and bloated bureaucracies.

Table 1 shows some data cited by the IMF for 2002, before the end of the specialized institutions and their merger into the commercial banking system. In only the past three years, considerable progress has been made in ending the special status of these institutions in the credit creation and finance process. As the legacy of their poor performance disappears from the books of the private sector that took over their assets and liabilities, the financial system will grow even stronger, as will its ability to contribute to economic development.

Table 1

Specialized banks have been a drag on the performance of an otherwise strong financial system (2002)

\begin{tabular}{|l|c|c|c|}
\hline & $\begin{array}{c}\text { Commercial } \\
\text { banks }\end{array}$ & $\begin{array}{c}\text { Specialized } \\
\text { banks }\end{array}$ & All banks \\
\hline $\begin{array}{l}\text { Bank capital } \\
\text { (\% of risk-weighted assets) }\end{array}$ & $15.3 \%$ & $0.5 \%$ & $12.5 \%$ \\
\hline $\begin{array}{l}\text { Non-performing loans (NPLs) } \\
\text { (percent of total loans) }\end{array}$ & 11.3 & 36.4 & 18.0 \\
\hline $\begin{array}{l}\text { Provisions } \\
\text { (percent of NPLs) }\end{array}$ & 70.3 & 34.6 & 53.8 \\
\hline Rate of return on assets & 1.1 & -1.0 & 0.7 \\
\hline Rate of return on equity & 11.8 & -10.0 & 7.8 \\
\hline
\end{tabular}

Table 1 shows that the performance of the commercial banking system was satisfactory by international standards: a strong level of bank capital, average non-performing loans with aggressive provisioning, and average rates of return. When the dismal indicators for the specialized banks are averaged, the performance of the overall banking system was 
dragged down, showing adequate capital, but high losses, inadequate provisioning and relatively low profitability indicators.

\section{Obstacles to a strong financial system}

While the problems posed by specialized banks are rolling off the balance sheets of the economy, another and greater obstacle to financial sector and economic development remains. Morocco has been plagued by relatively large budget deficits for decades. And the outlook is not favorable, with some experts suggesting that Morocco could run budget deficits of 3 percent of GDP or more for the indefinite future without serious damage to the economy or its growth prospects. Interestingly, this is the threshold used earlier for European Union (EU) economies to gain admission to membership in the European Central bank and continues to be the tripwire for required adjustment under the EU's growth and stability pact.

The financial system, though robust, is impaired by having to take on excessive quantities of low risk-low return government debt at the expense of riskier, but more productive private sector lending. This is the financial sector's side of the "crowding-out" of private sector investment that is expected from government expenditures and budget deficits. But it also points up the fact that loading up a bank's balance sheet with government debt, not only crowds out other lending, but that it also reduces the profitability and growth incentives of the financial sector. By reducing funds available for private lending, the budget deficit raises the loan rates on such loans, a notable problem in Morocco, despite low inflation and a favorable risk environment.

Another fiscal barrier to financial sector development is the extremely high tax burden and burden of excessive government size. For example, a maximum tax rate of 44 percent is reached at relatively low incomes of about $\$ 7000$ per year. Such a high tax rate substantially reduces rates of return and saving and investment incentives and taxes risk taking and entrepreneurship, already relatively scarce, very heavily. Other financial sectors are weaker, especially insurance and security markets. Fostering a stronger insurance sector would also deepen the market for long-term debt, a critical factor for domestic capital formation.

The government has pursued a strategy of reducing foreign indebtedness by substituting domestic debt. This policy has been successful and it has reduced the vulnerability of the economy to shocks in the international capital market. Foreign debt is now a modest share of GDP or of the nation's exports, which is very favorable today. For example, external debt as a percent of grow national income has fallen from about 130 percent in 1986 to about 40 percent in recent years. The latter is a very respectable and acceptable level for international capital markets. At the same time, however, domestically held government debt has climbed to over 70 percent of gross national income. This substitution has placed a greater burden on the country's financial system and of course means that the budget struggles with an increasing share of interest expenses, funds for which could have been put to more desirable social programs. Because of the limitations on funds for private lending and the relatively low return on government bonds, banks have limited funds 
available for private lending and do so at much higher required lending rates. Both factors impede private sector borrowing and economic development.

\section{Exchange controls limit competition and financial sector development}

Morocco's exchange rate policy provides an anchor for price stability, as highlighted above, but it is backed up by strict exchange controls that limit access by Moroccan investors to the global marketplace. As a result, domestic financial institutions face little competition and rates of return available to savers and overall saving itself suffer. At the same time, limits on saving and returns make capital scarcer for private sector activity, limiting growth. The IMF (2003) has advised that the central bank move away for its exchange rate targeting efforts and open its capital markets more fully. Certainly the latter step could boost growth and the strength of the financial sector, despite the heavy dose of foreign competition that it would introduce.

\section{References}

El Aynaoui, Karim, “Le Financement: Politique Monetaire et Systemes d'Incitation,” Paper presented at the conference: "The Moroccan Financial System and Economic Opportunities,” Casablanca, Morocco, September 19, 2005.

International Monetary Fund, "Morocco: Financial System Stability Assessment," IMF Country Report 03/212, July 2003. 